\title{
A meta-analysis of the effects of dietary supplementation in tropical forage-fed cattle
}

\section{Efeito da suplementação de bovinos de corte em pastagem tropical: abordagem meta-analítica}

\author{
Gilmar dos Santos Cardoso ${ }^{1 *}$; Diego Soares Machado ${ }^{1}$; Larissa Luísa Schumacher ${ }^{2}$; \\ Caroline de Avila Fernandes ${ }^{3}$; Dieison Pansiera Antunes ${ }^{4}$; Michael dos Santos \\ Schenkel $^{4}$; Alice Züge Rodrigues ${ }^{4}$; Ivan Luiz Brondani ${ }^{5}$
}

\section{Highlights:}

Tropical pastures sometimes do not meet the requirements of cattle, regardless of supply. Concentrated grazing supplementation makes the production system more efficient. Rearing cattle are more dependent on protein supplements.

\begin{abstract}
The objective of this study was to, through a meta-analysis of published data, evaluate the effects of dietary supplementation on the performance of beef cattle grazed on Brachiaria pastures during the rearing and finishing phases of growth. Data from 15 Brazilian studies were analyzed, totaling 462 animals given different types and levels of supplementation. Animals were divided into two categories: 319 in the rearing phase, and 143 in the finishing phase. The reviewed studies evaluated the effects of protein, energy, and protein/energy supplementation on animal performance parameters. Daily weight gain and final live weight were analyzed using forest plots. Daily weight gain during the rearing phase was similar across all supplement types used. Animals given supplementation gained an average of $119 \mathrm{~g}$ more per day compared to those who received no supplementation. Specifically, protein supplementation resulted in an increase of $28.22 \mathrm{~kg}$. Animals given supplementation of any kind, represented by the subgroups shown in the plots, gained an average of $24.47 \mathrm{~kg}$ more compared to the control group.
\end{abstract}

Key words: Brachiaria. Forest plot. Weight gain. Final live weight.

\section{Resumo}

O objetivo desse estudo foi avaliar por meio metanalítico os efeitos da suplementação no desempenho durante as fases de recria e terminação de bovinos de corte em pastagem de Brachiaria. Foram analisados dados combinados de 15 estudos nacionais, com um número total de 462 bovinos, submetidos à pastejo

1 Drs. em Zootecnia, Universidade Federal de Santa Maria, UFSM, Santa Maria, RS, Brasil. E-mail: cardoso-gilmar@bol.com.br; dsm_zootecnista@hotmail.com

2 Discente do Curso de Mestrado do Programa de Pós-Graduação em Zootecnia, UFSM, Santa Maria, RS, Brasil. E-mail: larischumacher@hotmail.com

3 Zootecnista, UFSM, Santa Maria, RS, Brasil. E-mail: fernandescaroline.2014@gmail.com

4 Discentes do Curso de Graduação em Zootecnia, UFSM, Santa Maria, RS, Brasil. E-mail: dieisonpansiera@hotmail.com; michaelschenkel14@gmail.com; alicezuge95@gmail.com

5 Prof. Dr. em Zootecnia, UFSM, Santa Maria, RS, Brasil. E-mail: ivanbrondani@gmail.com

"Author for correspondence 
em forragem tropical com diferentes tipos e níveis de suplementação. Esses animais foram divididos em duas categorias; 319 na fase de recria e 143 na fase de terminação. Os trabalhos revisados avaliaram o efeito da suplementação proteica, energética e proteica-energética sobre parâmetros de desempenho animal. As variáveis, ganho de peso diário e peso vivo final foram analisadas através de Forest plot. O ganho de peso diário na fase de recria apresentou semelhança entre os tipos de suplementos fornecidos aos animais. Os animais que recebiam suplemento no pastejo apresentaram maior ganho de peso diário em relação ao grupo controle, com incremento de $119 \mathrm{~g} \mathrm{dia}^{-1}$. A suplementação proteica possibilitou aos animais incremento de $28,22 \mathrm{~kg}$ em relação àqueles que não recebiam nenhum tipo de nutriente a não ser da própria pastagem. Diferenciando-se apenas dos animais que não recebiam suplementação nesse período, o ganho de peso final adicional dos subgrupos em relação ao controle foi de $24,47 \mathrm{~kg}$.

Palavras-chave: Brachiaria. Forest plot. Ganho de peso. Peso vivo final.

\section{Introduction}

Beef production in Brazil is significantly important in the world market due to the country's natural resources, which support herd-development through forage, thus favoring increased production. In Brazil, forage grasses of the expressive genus Brachiaria are common. Depending on soil and climate conditions, the most common species include Brachiaria decumbens, Brachiaria brizantha, and Brachiaria humidicola. Together, these three species populate approximately $85 \%$ of the pastures in central Brazil (Empresa Brasileira de Pesquisa Agropecuária - Centro Nacional de Pesquisa em Gado de Corte [EMBRAPA-CNPGC], 2019). However, seasonal changes (predominantly during the dry season), decrease the nutritional value of these grasses due to degradation of the pastures; thus, resulting in low zootechnical performance (Moraes et al., 2012).

Considering the behavior of forage animals, it is important for the rural producer to stipulate objectives in the development process of the animal. Even during periods of maximum forage production, the nutritional requirements of the cattle may not be met, especially for growing animals. Nutritional deficiency results in a reduction in the rate and maximum capacity of weight gain, subsequently leading to higher expenses during the finishing phase. Consequently, the use of concentrated supplements in either season could correct specific nutrient deficiencies. Supplements are typically given at low levels to increase nutrient-availability for ruminal bacteria, improving use of the structural carbohydrates obtained from the pasture; thus, resulting in better animal performance. Therefore, in each situation it is necessary to analyze which type of supplement is appropriate to improve production rates.

We conducted a meta-analysis to evaluate the effects of dietary supplementation on the performance of cattle grazed in Brachiaria pastures during the rearing and finishing phases.

\section{Materials and Methods}

Data from 15 Brazilian studies were analyzed, totaling 462 animals grazed on tropical forage with different types and levels of supplementation. Animals were divided into two categories: 319 in the rearing phase, and 143 in the finishing phase (Table 1). The reviewed studies evaluated the effect of protein, energy, and protein/energy supplementation on parameters of animal performance. Literature published from 2004-2015 was found through the Scientific Electronic Library Online (http://www. scielo.br) or CAPES periodical portal (http://www. periodicos.capes.gov.br), using keywords: beef cattle OR supplementation OR pasture AND weight gain OR animal performance. Included studies must have had a control group without supplementation, used forage of the genus Brachiaria, took place in the tropical region of Brazil, and analyzed the daily weight gain and final body weight. 
Animal performance parameters included the initial live weight (ILW), final live weight (FLW), and daily weight gain (DWG) for each phase. Data from the rearing and finishing phases varied greatly in ILW due to different body structure and development. Therefore, the mean live weight was $248.6 \mathrm{~kg}$ and $367.2 \mathrm{~kg}$ for the phases of rearing and finishing, respectively. Importantly, while all studies used Brachiaria forage, they were conducted during different times of the year, therefore, the performance of the animals was evaluated in the dry and wet seasons, with a mean forage mass of 6.56 ton $\mathrm{ha}^{-1}$.

Table 1

Details and information on the studies included in the metanalysis

\begin{tabular}{cccccc}
\hline Studies & Published & $\mathrm{n}$ & Forage & Categories & Treatment \\
\hline 1 & Reis et al. (2012) & 50 & Capim Marandu & Rearing & Prot./energ. \\
2 & Porto et al. (2011) & 30 & Brachiaria decumbens Stapf & Rearing & Prot./energ. \\
3 & Alonso et al. (2014) & 75 & Brachiaria Brizantha cv. Marandu & Rearing & Prot./energ. \\
4 & Lima et al. (2012) & 15 & Brachiaria Brizantha cv. Piatã & Rearing & Prot./energ. \\
5 & Porto et al. (2009) & 25 & Brachiaria Brizantha cv. Marandu & Rearing & Protein \\
6 & Nogueira et al. (2015) & 39 & Brachiaria brizantha e decumbens & Rearing & Protein \\
7 & Lima et al. (2012) & 5 & Brachiaria Brizantha cv. Piatã & Rearing & Protein \\
8 & Sales et al. (2011) & 25 & Brachiaria decumbens Stapf & Rearing & Protein \\
9 & Socreppa et al. (2015) & 30 & Brachiaria Brizantha cv. Marandu & Rearing & Energy \\
10 & Alonso et al. (2014) & 25 & Brachiaria Brizantha cv. Marandu & Rearing & Energy \\
11 & Porto et al. (2008) & 16 & Brachiaria decumbens Stapf & Finishing & Prot./energ. \\
12 & Baroni et al. (2010) & 48 & Brachiaria Brizantha cv. Marandu & Finishing & Protein \\
13 & Detman et al. (2004) & 25 & Brachiaria decumbens Stapf & Finishing & Protein \\
14 & Botini et al. (2015) & 30 & Capim Marandu & Finishing & Energy \\
15 & Sales et al. (2008) & 24 & Brachiaria Brizantha cv. Marandu & Finishing & Energy \\
\hline Total & - & 462 & & - & - \\
\hline
\end{tabular}

DWG and FLW were analyzed using a forest plot. First, a funnel plot analysis was conducted to assess whether there was publication bias in the meta-analysis. All studies used had a treatment without supplementation, which we combined into a control group for our analysis. The other three treatments: protein, energy, and protein/energy supplementation, were considered subgroups. For each study, the number of events, averages, and standard deviations were tabulated using Excel (Microsoft Office), and analyzed in R (version 3.3.2) using the metacont function, which is included in the meta package. Graphs were built for each variable using the forest function, one for each phase (rearing and finishing). However, the finishing phase protein/ energy subgroup only included dispersion data from one study, making it impossible to compare to other subgroups. Thus, this subgroup was removed from the forest plot.

Heterogeneity among the experiments included was quantified using the $\mathrm{I}^{2}$ test (Higgins, Thompson, Deeks, \& Altman, 2002), which quantifies the impact of heterogeneity on a meta-analysis using mathematical criteria independently on number of studies and metric effect of the treatment. The random model was chosen due to the heterogeneity of the analyzed results. 


\section{Results and Discussion}

DWG in the rearing phase was similar across protein, energy, and protein/energy supplementation regimens (Figure 1), and was always higher compared to that of cattle not given supplementation. The forest plot shows the lozenges, representing each type of supplementation in the meta-analysis, align on the positive side of the same axis $(p>0.05)$, demonstrating a similar response. Garcia, Euclides, Alcalde, Difante and Medeiros (2014) evaluated the performance of $B$. decumbens 'Basilisk'fed crossbred cattle (Braford x Angus x Nellore) supplemented with protein mineral salt $0.2 \%$ of the body weight, and reported a weight gain of 0.630 $\mathrm{kg}$, which is close to the mean weight gain we found in cattle receiving supplementation.

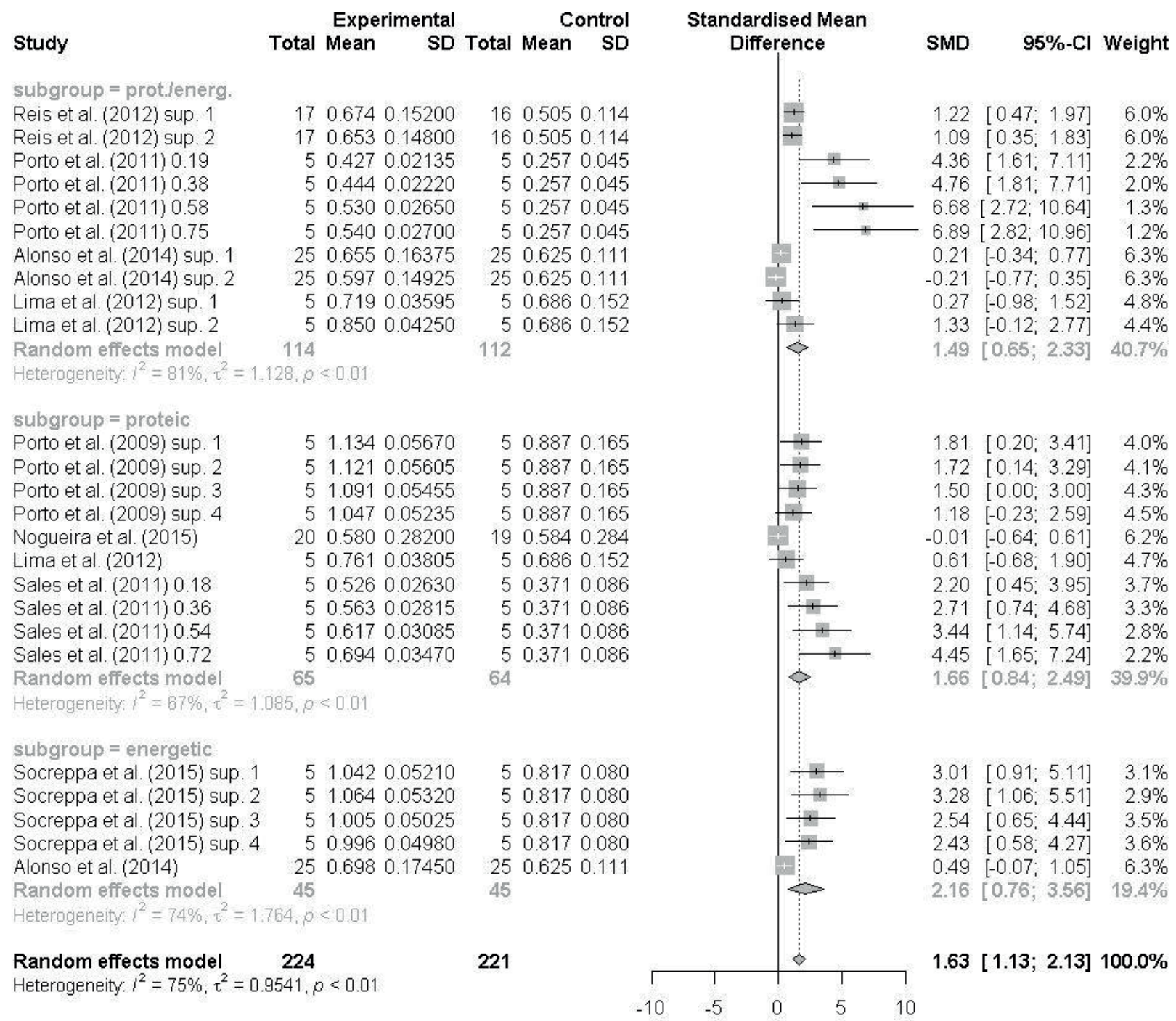

Figure 1. Forest plot of the daily weight gain (DWG) of tropical forage-fed rearing-phase cattle that received different dietary supplements.

Figure 1 also shows that animals receiving supplementation had greater DWG than the control group, with an average increase of $119 \mathrm{~g} \mathrm{day}^{-1}$ among the subgroups. This finding is associated with a higher nutritional level and biological efficiency in the rearing animals receiving supplementation during the phase of physiological development. Nascimento et al. (2010) showed that the mean 
daily gain of animals given supplementation was $33.4 \%$ higher than the gain of the animals receiving only the mineral mixture, which corresponds to an increase of $150 \mathrm{~g} \mathrm{day}^{-1}$.

As for the FLW of rearing cattle (Figure 2), the protein/energy and energy supplementation subgroups showed uniform results $(\mathrm{p}>0.05)$. In contrast, protein supplementation resulted in an increase of $28.22 \mathrm{~kg}$ compared to control animals. This is likely because as the animals grow, more protein is needed for muscle tissue. Fernandes, Reis and Paes et al. (2010) reported an increase of $30 \mathrm{~kg}$ in the final weight of supplemented animals.

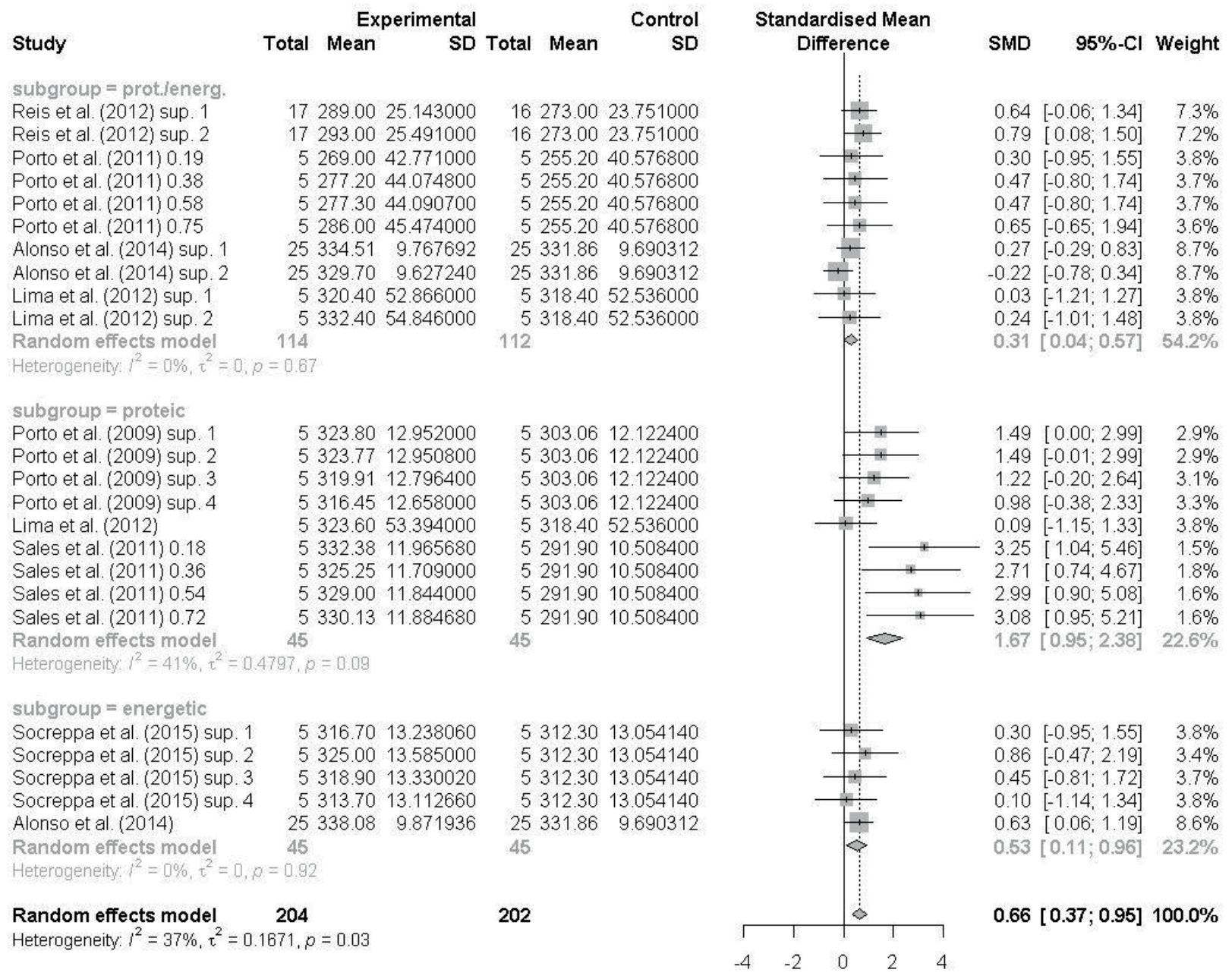

Figure 2. Forest plot for final live weight (FLW) of tropical forage-fed rearing-phase cattle that received different supplements.

For additional weight gain during the rearing phase in supplemented animals, the subgroups showed that cattle receiving protein supplementation had $61.12 \%$ and $76.29 \%$ more weight gain than animals receiving protein/energy or energy supplements, respectively. Such results demonstrate better efficiency of protein supplementation during the development phase.

Despite the different seasons during which the studies used occurred, Brachiaria did not provide enough nutrients to meet the requirement of animals at this age, regardless of receiving forage 
in greater quantity and with higher quality. Thus, the supplementation strategy can be used when the forage is deficient for specific nutrients, increasing dry-matter consumption and improving digestibility (Koscheck et al., 2011).

Animals have lower protein requirements during the finishing phase, resulting in greater energy for fat deposition and improving carcass finishing. Energy supplementation in diets based on good quality forage can improve the efficiency of $\mathrm{N}$ use, decreasing the acetate to propionate ratio (A:P), and consequently decreasing methane production (Rivera et al., 2010).

Figure 3 shows DWG in the finishing phase. The two subgroups analyzed for this variable showed similar responses. The two lozenges of the supplements are on the same line, with no difference in daily gain for the two groups. However, even with evident similarity, the DWG of the energy supplementation group is $41.53 \%$ higher than the protein group, proving that higher energy levels in the finishing phase result in better animal responses.

\begin{tabular}{|c|c|c|c|c|c|c|c|c|}
\hline \multirow{2}{*}{ Study } & \multicolumn{2}{|r|}{ Experimental } & \multicolumn{2}{|r|}{ Control } & \multirow{2}{*}{$\begin{array}{l}\text { Standardised Mean } \\
\text { Difference }\end{array}$} & \multirow[b]{2}{*}{ SMD } & \multirow[b]{2}{*}{$95 \%-\mathrm{Cl}$} & \multirow[b]{2}{*}{ Weight } \\
\hline & Total & Mean SD & Total & Mean SD & & & & \\
\hline \multicolumn{9}{|l|}{ subgroup $=$ proteic } \\
\hline Baroni et al. (2010) 0.05 & 8 & 0.1950 .01560 & 8 & 0.2870 .145 & + & -0.84 & {$[-1.88 ; 0.19]$} & $8.5 \%$ \\
\hline Baroni et al. (2010) 0.11 & 8 & 0.0990 .00792 & 8 & 0.2870 .145 & + & -1.73 & {$[-2.93 ;-0.53]$} & $8.3 \%$ \\
\hline Baroni et al. (2010) 0.23 & 8 & 0.2740 .02192 & 8 & 0.2870 .145 & + & -0.12 & {$[-1.10 ; 0.86]$} & $8.5 \%$ \\
\hline Baroni et al. $(2010) 0.46$ & 8 & 0.3720 .02976 & 8 & 0.2870 .145 & + & 0.77 & {$[-0.26 ; 1.79]$} & $8.5 \%$ \\
\hline Baroni et al. (2010) 0.91 & 8 & $0.588 \quad 0.04704$ & 8 & 0.2870 .145 & $\div$ & 2.64 & {$[1.20 ; 4.08]$} & $8.0 \%$ \\
\hline Detman et al. (2004) sup. 1 & 5 & 0.6840 .03420 & 5 & 0.2770 .056 & +1 & 7.92 & {$[3.29 ; 12.55]$} & $4.0 \%$ \\
\hline Detman et al. (2004) sup. 2 & 5 & 0.8110 .04055 & 5 & 0.2770 .056 & 1 & 9.87 & {$[4.17 ; 15.56]$} & $3.1 \%$ \\
\hline Detman et al. (2004) sup. 3 & & $0.983 \quad 0.04915$ & 5 & 0.2770 .056 & $\rightleftarrows$ & -12.10 & {$[5.18 ; 19.03]$} & $2.4 \%$ \\
\hline Detman et al. (2004) sup. 4 & 5 & $0.800 \quad 0.04000$ & 5 & 0.2770 .056 & $\mp$ & 9.71 & {$[4.10 ; 15.31]$} & $3.2 \%$ \\
\hline Random effects model & 60 & & 60 & & $<$ & 2.41 & {$[0.67 ; 4.15]$} & $54.4 \%$ \\
\hline \multicolumn{9}{|c|}{ Heterogeneity. $/^{2}=89 \%, \tau^{2}=4.816, p<0.01$} \\
\hline \multicolumn{9}{|l|}{ subgroup $=$ energetic } \\
\hline Botini et al. (2015) sup. 1 & & $0.980 \quad 0.04900$ & 5 & $0.390 \quad 0.108$ & 1 & 6.35 & {$[2.57 ; 10.14]$} & $4.9 \%$ \\
\hline Botini et al. (2015) sup. 2 & 5 & 1.1100 .05550 & 5 & 0.3900 .108 & 1 & 7.57 & {$[3.13 ; 12.01]$} & $4.2 \%$ \\
\hline Botini et al. (2015) sup. 3 & 5 & $0.910 \quad 0.04550$ & 5 & $0.390 \quad 0.108$ & 1 & 5.67 & {$[2.24 ; 9.09]$} & $5.3 \%$ \\
\hline Botini et al. (2015) sup 4 & 5 & $0.680 \quad 0.03400$ & 5 & $0.390 \quad 0.108$ & $\div$ & 3.27 & {$[1.05 ; 5.49]$} & $7.0 \%$ \\
\hline Sales et al. (2008) 0.27 & 6 & $0.614 \quad 0.03684$ & 6 & 0.5110 .094 & F. & 1.33 & {$[0.03 ; 2.64]$} & $8.2 \%$ \\
\hline Sales et al. (2008) 0.40 & 6 & $0.664 \quad 0.03984$ & 6 & 0.5110 .094 & $\mp$ & 1.96 & {$[0.48 ; 3.44]$} & $8.0 \%$ \\
\hline Sales et al. (2008) 0.54 & 6 & 0.6290 .03774 & 6 & 0.5110 .094 & + & 1.52 & {$[0.17 ; 2.87]$} & $8.1 \%$ \\
\hline \multicolumn{9}{|c|}{ Heterogeneity: $i^{2}=66 \%, \tau^{2}=1.997, p<0.01$} \\
\hline Random effects model & 98 & & 98 & & $\dot{\phi}$ & \multirow{3}{*}{\multicolumn{3}{|c|}{$2.81[1.57 ; 4.05] 100.0 \%$}} \\
\hline \multirow{2}{*}{\multicolumn{5}{|c|}{ Heterogeneity. $i^{2}=86 \%, \tau^{2}=4.433, p<0.01$}} & 11 & & & \\
\hline & & & & & $\begin{array}{lllllll}-15 & -10 & -5 & 0 & 5 & 10 & 15\end{array}$ & & & \\
\hline
\end{tabular}

Figure 3. Forest plot for daily weight gain (DWG) of tropical forage-fed finishing-phase cattle that received different supplements.

Figure 3 also shows a daily gain difference between the groups of supplemented animals compared to those that were finished only in pasture. Protein and energy supplementation showed a gain increase of $102 \mathrm{~g} \mathrm{day}^{-1}$ compared to the control group, showing that the use of Brachiaria grazing supplements improves productive performance. In general, cattle graze on forage with low nutritional value, with high levels of indigestible fiber and low levels of crude protein. According to Carvalho et al. (2014), protein supplementation to cattle in tropical forages increases the supply of ammoniacal nitrogen to ruminal microorganisms, increasing forage consumption. 
Figure 4 shows FLW in finishing-phase animals, which was similar to the forest plot of DWG for the same phase. Animals in the supplemented groups presented a balanced performance, demonstrating that energy supplementation did not increase their final weight when compared with protein supplementation. Differently from the animals not receiving supplementation in this period, the subgroups presented an additional FLW of 24.47 $\mathrm{kg}$ compared to the control group. As seen in other parameters for this phase of growth, all lozenges are located on the positive (right) side, demonstrating the benefit of either protein or energy supplementation on the performance of cattle grazed in tropical pastures.

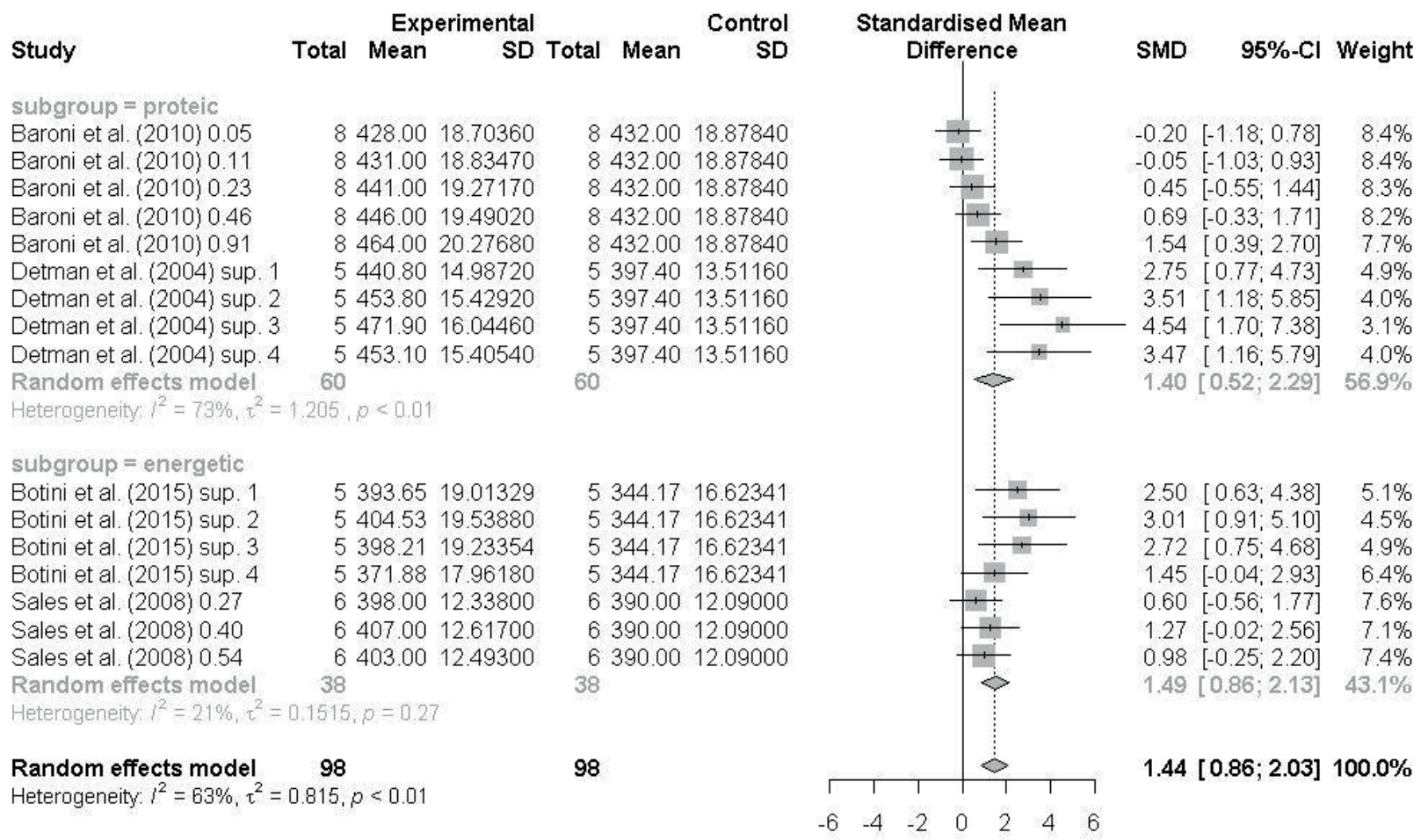

Figure 4. Forest plot for final live weight (FLW) of tropical forage-fed finishing-phase cattle that received different supplements.

\section{Conclusions}

Dietary protein and/or energetic supplementations for cattle grazed on Brachiaria improves the performance of these animals. Protein supplementation beneficially effects the FLW of animals specifically during the rearing phase.

\section{References}

Alonso, M. P., Moraes, E. H. B. K., Pina, D. S., Pereira, D. H., Mombach, M. A., Gimenez, B. M., \& Wruck, F. J. (2014). Suplementação concentrada para bovinos de corte em sistema de integração lavoura e pecuária no período das águas. Revista Brasileira de Saúde e Produção Animal, 15(2), 339-349. doi: 10.1590/ S1519-99402014000200018

Baroni, C. E. S., Lana, R. P., Mancio, A. B., Queiroz, A. C., Sverzut, C. B., \& Mendonça, B. P. C. (2010). Desempenho de novilhos suplementados e terminados em pasto, na seca, e avaliação do pasto. Arquivo Brasileiro de Medicina Veterinária 
e Zootecnia, 62(2), 373-381. doi:10.1590/S010209352010000200018

Botini, L. A., Moraes, K. A. K., Moraes, E. H. B. K., Pina, D. S., Paula, D. C., Hoffmann, A., Stinguel, H., Socreppa, L. M., \& Meneses, D. M. (2015). Glicerina bruta em suplementos para bovinos de corte a pasto no período seco. Pesquisa Agropecuária Brasileira, 50(3), 242-249. doi: 10.1590/S0100204X2015000300008

Carvalho, D. M. G., Cabral, L. S., Zervoudakis, J. T., Moraes, E. H. B. K., Benatti, J. M. B., Koscheck, J. F. W., \& Oliveira, A. A. (2014). Eficiência bioeconômica da suplementação de novilhos em pastagens de Capim Marandu. Semina: Ciências Agrárias, 35(4), 2685-2698. doi: 10.5433/16790359.2014v35n4 Suplp2685

Detmann, E., Paulino, M. F., Zervoudakis, J. T., Cecon, P. R., Valadares S. C. Fo., Gonçalves, L. C., Cabral, L. S., \& Melo, A. J. N. (2004). Níveis de proteína bruta em suplementos múltiplos para terminação de novilhos mestiços em pastejo durante a época seca: desempenho produtivo e características de carcaça. Revista Brasileira de Zootecnia, 33(1), 169180. doi:10.1590/S1516-35982004000100021

Empresa Brasileira de Pesquisa Agropecuária - Centro Nacional de Pesquisa em Gado de Corte (2019). Brachiaria brizantha cv. marandu. Brasília: Livraria Embrapa. Recuperado de http://www.cnpgc. embrapa.br

Fernandes, L. O., Reis, R. A., \& Paes, J. M. V. (2010). Efeito da suplementação no desempenho de bovinos de corte em pastagem de Brachiaria brizantha cv. marandu. Ciência e Agrotecnologia, 34(1), 240-248. doi: 10.1590/S1413-70542010000100031

Garcia, J., Euclides, V. P. B., Alcalde, C. R., Difante, G. S., \& Medeiros, S. R. (2014). Consumo, tempo de pastejo e desempenho de novilhos suplementados em pastos de Brachiaria decumbens, durante o período seco. Semina: Ciências Agrárias, 35(4), 2095-2106. doi: 10.5433/1679-0359.2014v35n4p2095

Higgins, J. P., Thompson, S. G., Deeks, J. J., \& Altman, D. G. (2002). Measuring inconsistency in metaanalyses. British Medical Journal, 327(257), 557560. doi: 10.1136/bmj.327.7414.557

Koscheck, J. F. W., Zevoudakis, J. T., Carvalho, D. M. G., Cabral, L. S., Amorim, K. P., Silva, R. G. F., \& Silva, R. P. (2011). Suplementação de bovinos de corte em sistema de pastejo. UNICiências, 15(1), 377-412. doi: $10.17921 / 1415-5141.2011 \mathrm{v} 15 \mathrm{n} 1 \mathrm{p} \% 25 \mathrm{p}$
Lima, J. B. M. P., Rodríguez, N. M., Martha. G.B. Jr, Guimarães, R. Jr., Vilela, L., Graça, D. S., \& Saliba, E. O. S. (2012). Suplementação de novilhos Nelore sob pastejo, no período de transição águasseca. Arquivo Brasileiro de Medicina Veterinária e Zootecnia, 64(4), 943-952. doi: 10.1590/S010209352012000400022

Moraes, E. H. B. K., Paulino, M. F., Zervoudakis, J. T., Detmann, E., Valadares, S. C., Fo., \& Moraes, K. A. K. (2012). Aspectos produtivos e econômicos de novilhos mestiços alimentados com suplementos proteico-energéticos contendo ureia. Revista Brasileira de Zootecnia, 41(5), 1278-1284. doi: 10.1590/ S1516-35982012000500027

Nascimento, M. L., Paulino, M. F., Detmann, E., Leão, M. I., Valadares, S. C., F ${ }^{\mathrm{o}}$, \& Henriques, L. T. (2010). Fontes de energia em suplementos múltiplos para novilhos em pastejo durante o período das águas. Revista Brasileira de Zootecnia, 39(4), 861-872. doi: 10.1590/S1516-35982010000400023

Nogueira, A. P. C., Alvarenga, P. B., Ferreira, I. C., Rios, M. P., \& Silva, C. R. (2015). Desempenho ponderal e reprodutivo no período das águas de novilhas primíparas nelore com complemento proteico prévio na seca. Ciência Animal Brasileira, 16(3), 331-342. doi: 10.1590/1089-6891v16i324160

Porto, M. O., Paulino, M. F., Valadares, S. C. Fº, Sales, M. F. L., Detmann, E., \& Cavali, J. (2008). Formas de utilização do milho em suplementos para novilhos na fase de terminação em pastagem no período das águas: desempenho e parâmetros nutricionais. Revista Brasileira de Zootecnia, 37(12), 2251-2260. doi: 10.1590/S1516-35982008001200024

Porto, M. O., Paulino, M. F., Valadares, S. C. Fo., Sales, M. F. L., Leão, M. I., \& Couto, V. R. M. (2009). Fontes suplementares de proteína para novilhos mestiços em recria em pastagens de capim-braquiária no período das águas: desempenho produtivo e econômico. Revista Brasileira de Zootecnia, 38(8), 1553-1560. doi: 10.1590/S1516-35982009000800020

Porto, M. O., Paulino, M. F., Detmann, E., Valadares, S. C. Fo., Sales, M. F. L., Cavali, J., Nascimento, M. L., \& Acedo, T. S. (2011). Ofertas de suplementos múltiplos para tourinhos Nelore na fase de recria em pastagens durante o período da seca: desempenho produtivo e características nutricionais. Revista Brasileira de Zootecnia, 40(11), 2548-2557. doi: 10.1590/S1516-35982011001100037

Reis, R. A., Ruggieri, A. C., Oliveira, A. A., Azenha, M. V., \& Casagrande, D. R. (2012). Suplementação 
como estratégia de produção de carne de qualidade em pastagens tropicais. Revista Brasileira de Saúde e Produção Animal, 13(3), 642-655. doi: 10.1590/ S1519-99402012000300005

Rivera, A. R., Berchielli, T. T., Messana, J. D., Veslasquez, P. T., Franco, A. V. M., \& Fernandes, L. B. (2010). Fermentação ruminal e produção de metano em bovinos alimentados com feno de capim-tifton 85 e concentrado com aditivos. Revista Brasileira de Zootecnia, 39(3), 617-624. doi: 10.1590/S151635982010000300022

Sales, M. F. L., Paulino, M. F., Porto, M. O., Valadares, S. C. Fo., Acedo, T. S., \& Couto, V. R. M. (2008). Níveis de energia em suplementos múltiplos para terminação de novilhos em pastagem de capimbraquiária no período de transição águas-seca. Revista Brasileira de Zootecnia, 37(4), 724-733. doi: 10.1590/S1516-35982008000400020
Sales, M. F. L., Paulino M. F., Valadares, S. C. F . Figueiredo, D. M., Porto, M. O., \& Detmann, E. (2011). Supplementation levels for growing beef cattle grazing in the dry-rainy transition season. Revista Brasileira de Zootecnia, 40(4), 904-911. doi: 10.1590/S1516-35982011000400027

Socreppa, L. M., Moraes, E. H. B. K., Moraes, K. A. K., Oliveira, A. S., Drosghic, L. C. A. B., Botini, L. A., \& Stinguel, H. (2015). Glicerina bruta para bovinos de corte em pastejo no período das águas: viabilidade produtiva e econômica. Revista Brasileira de Saúde e Produção Animal, 16(1), 232-243. doi: 10.1590/ S1519-99402015000100024 
